\title{
Schopenhauer's Rejection of the Moral Ought
}

\author{
Stephen Puryear \\ North Carolina State University \\ "In a practical philosophy, [...] we have to do not with assuming grounds for what happens \\ but rather laws of what ought to happen even if it never does, that is, objective practical laws." \\ (Kant, G 4:427) ${ }^{1}$ \\ "We will not talk about 'oughts' at all: that is how you talk to children, or to nations in their \\ infancy, not to those who have acquired all the culture of a mature age." \\ (Schopenhauer, WWR 1, §53, 320)
}

Kant's statement expresses the still widely accepted view that morality takes a prescriptive form: it concerns what in some sense ought to happen, even if it never does happen. An ought, Kant tells us earlier in the Groundwork, is that through which an imperative is expressed, and an imperative is the formula of a command or law (of reason) ( $G$ 4:413). Morality is thus from this perspective a system of oughts, imperatives, commands, laws. And on the common view, as on Kant's, these oughts or imperatives of morality are thought to bind us in a particularly strong fashion, that is, categorically or absolutely. In short, they tell us what we must do, or must not do, come what may.

This conception of morality as a system of categorically binding oughts or imperatives has more recently come under fire, perhaps most notably at the hands of Elizabeth Anscombe (1958) and Philippa Foot (1972). ${ }^{2}$ To my mind, however, the most forceful and most interesting critique of the prescriptive conception of morality, though one not so well known today, was advanced more than a century earlier by Arthur Schopenhauer, first in his The World as Will and Representation (1818) and more fully in his unsuccessful prize-essay On the Basis of Morality (1839). My aim here will be to reconstruct and sharpen his critique, and to argue that it does in fact cast serious doubt on the prescriptivist conception of morality.

I understand Schopenhauer's critique to consist of four main objections. According to the first, which I consider in Section 1, Kant begs the question by merely assuming that ethics has a prescriptive or legislative-imperative form, when a purely descriptive conception such as Schopenhauer's also presents itself as a possibility. In Section 2, I set the stage for the remaining objections by elucidating, sharpening, and

\footnotetext{
${ }^{1}$ See also CPR A802/B830; MM 6:216.

${ }^{2}$ See also Slote (1982); Williams (1985: 174-96); Taylor (2000: 139-77); Taylor (2002: 77-84); see Capaldi (1966) for an argument that Hume means to reject "ought" as a moral category.
} 
defending a principle of Schopenhauer's on which they all depend: namely, that a binding ought must be understood to presuppose, and be conditioned by, a threat of punishment or promise of reward. In Section 3, I turn to Schopenhauer's second objection, which anticipates Anscombe's point that the notion of a moral ought loses all intelligibility outside the framework of a divine law conception of ethics. I then note that, whereas Anscombe settles for arguing that we should jettison the moral ought (to the extent that we can) merely because, as a matter of historical fact, we have largely abandoned its theological presuppositions, Schopenhauer advances the stronger conclusion that the very idea of a moral ought is incoherent. I distinguish two basic arguments for this conclusion, which constitute, respectively, his third and fourth objections overall. According to the first of these, the subject of Section 4, Kant's conceptions of the moral law as a law of freedom, and of moral imperatives as categorical or unconditioned imperatives, are in fact contradictory. Finally, in Section 5, I turn to Schopenhauer's final and in my opinion most penetrating objection, which is that, given human nature as we know it, the idea of a "moral ought" is a contradiction in terms because an ought or binding law must be understood to operate through appeals to self-interest. I contend that this last argument is in fact sound and thus I conclude that Schopenhauer was right to conceive of ethics as a descriptive rather than prescriptive enterprise. ${ }^{3}$

\section{Kant's Petitio Principii}

In his critique of Kant's ethics, Schopenhauer claims that Kant's first mistake was to assume from the outset something that needs to be argued, namely, that morality takes the form of laws, commands, imperatives, oughts-in short, that morality is prescriptive. "Who tells you," he asks, "that there are laws to which our actions ought to be subordinate? Who tells you that what never happens ought to happen?-What justifies you in assuming this in advance and then straight away pressing on us an ethics in legislative-imperative form as the only one possible?" (BM §4, 120). Of course, if that were the only possible form that ethics could take, then Kant would not be begging any questions. But Schopenhauer emphasizes that ethics can take another form, what we might call a descriptive-explanatory rather than a legislative-imperative form. On his view, "the ethicist, as the philosopher in general, must be satisfied with explanation and interpretation of what is given, that is, what really exists or happens, so as to reach an understanding of it" (BM §4, 120). And that which is given, in the case of ethics, is fundamentally the phenomenon of the moral worth (moralischer Werth) of actions. Thus, says Schopenhauer,

\footnotetext{
${ }^{3}$ For further discussion of these and other aspects of Schopenhauer's critique of Kant's ethics, see, e.g., Tsarnoff (1910); Young (1984); Cartwright (1999: 254-63); Welsen (2005); Hassan (2019: 2-10).
} 
I set ethics the task of clarifying and explaining ways of acting among human beings that are extremely morally diverse, and tracing them back to their ultimate ground. So there remains no other path to the discovery of the foundation of ethics than the empirical one, namely investigating whether there are any actions at all to which we must assign genuine moral worth-which will be the actions of freely willed justice, pure loving kindness and real noblemindedness. These, then, are to be regarded as a given phenomenon that we have to explain correctly, i.e. trace back to their true grounds [....] This is the modest path towards which I direct ethics. (BM §13, 195)

The task of ethics, as conceived by Schopenhauer, is thus to give an account of which actions have moral worth, i.e., are morally good, which ones are morally bad or reprehensible, and what it is in virtue of which they have these respective qualities. That is exactly what Schopenhauer attempts to do in his own ethical writings, though I will not be concerned with his positive account here. ${ }^{4}$

There is nothing incoherent in the supposition that there is such a thing as morality, and that its content is exhausted by facts about what sorts of actions have moral worth, what sorts are morally bad or wrong, or neither. To say that there are such moral facts is not to say, or to imply, that there are other moral facts of a prescriptive nature, for example that we ought to perform morally good actions. The claim that an action is morally good or bad, right or wrong, need not be taken to entail that we ought or ought not to perform that action, at least not in the moral sense of 'ought'. A descriptive account of the various moral phenomena, that is, need not entail the existence of any moral prescriptions. It would therefore be inappropriate merely to assume that there are such things as moral prescriptions. That needs to be proved.

But is Kant in fact guilty of this charge? Arguably not. He does, to be sure, assume the existence of a moral law, and thus of a legislative-imperative form for ethics, at the beginning of the Groundwork. But later in that work, in Section III, he does come back around to offering a justification for that assumption. Put simply, he appears to argue that rational beings must have free will; that free will consists in autonomy, or self-legislation; and thus that rational beings must be subject to a moral law (G 4:44653). This argument may well be rubbish; it may even beg some question. But it does not seem fair to object that Kant merely assumes that there is a moral law, or that morality is prescriptive. This first criticism thus falls flat. ${ }^{5}$

\footnotetext{
${ }^{4}$ I discuss various aspects of his positive account in Puryear (2017) and Puryear (forthcoming).

${ }^{5}$ Schopenhauer's critique in On the Basis of Morality focuses specifically on the Groundwork (BM §3, 119); it is therefore beside the point whether in the second Critique Kant effectively renounces the argument from Groundwork III and instead merely posits the moral law as a "fact of reason" (CPrR 5:31, 47). For a good entry wedge into the controversies over the interpretation of these two texts, and their relationship, see Bojanowski (2017).
} 


\section{Imperatives and Their Binding Force}

Schopenhauer's other objections to the idea of a moral ought all hinge upon the thesis that an imperative or ought has no sense or meaning apart from an externally imposed incentive, namely, a threatened punishment or promised reward. He explains this most fully in On the Basis of Morality:

That ought has any sense [Sinn] and meaning [Bedeutung] at all only in relation to threatened punishment or promised reward. Thus, long before Kant was thought of, Locke already says: 'For since it would be utterly in vain, to suppose a rule set to the free actions of man, without annexing to it some enforcement of good and evil to determine his will; we must, where-ever we suppose a law, suppose also some reward or punishment annexed to that law.' (On Understanding, Bk. II, ch. 33, §6). So the ought is necessarily conditioned by punishment or reward [...]. But once those conditions are thought away the concept of ought remains empty of sense. (BM §4, 123)

My aim in this section is to elucidate and sharpen this thesis, and to defend it against a key Kantian objection. In the remaining sections of the chapter, I will turn to the objections that Schopenhauer builds on this foundation.

In support of his thesis, Schopenhauer appeals to Locke's observation that a law not backed by "some enforcement of good and evil" would be futile. In fact, the basic idea behind this conception of law has a rather more illustrious history than this one quotation might suggest. Locke's contemporary, Samuel Pufendorf, for instance, defines law in his On the Duty of Man and Citizen According to Natural Law (1673) as "a decree by which a superior obliges one who is subject to him to conform his actions to the superior's prescription" (Bk. I, Ch. 2, §2/1991: 27). He then explains that the law acquires this power to oblige, this binding quality, from the threat of a punishment:

Every complete law has two parts: the one part in which what is to be done or not done is defined, and the other which declares the punishment prescribed for one who ignores a precept or does what is forbidden. For because of the wickedness of human nature which loves to do what is forbidden, it is utterly useless to say "Do this!" if no evil awaits him who does not, and similarly, it is absurd to say, "You will be punished", without first specifying what deserves the punishment. (Bk. I, Ch. 2, $\S 7 / 1991: 29)$

Similarly, in his Principles of Moral and Political Philosophy (1785), William Paley argues that a law can oblige only through a sufficiently violent motive: 
A man is said to be obliged, "when he is urged by a violent motive resulting from the command of another." [...] [W] herever the motive is violent enough, and coupled with the idea of command, authority, law, or the will of a superior, there, I take it, we always reckon ourselves to be obliged. [...] And from this account of obligation it follows, that we can be obliged to nothing, but what we ourselves are to gain or lose something by: for nothing else can be a "violent motive" to us. As we should not be obliged to obey the laws, or the magistrate, unless rewards or punishments, pleasure or pain, somehow or other, depended upon our obedience; so neither should we, without the same reason, be obliged to do what is right, to practise virtue, or to obey the commands of God. (Bk. II, Ch. 2)

Finally, to mention just one other example, there is John Austin, the prominent legal theorist and a contemporary of Schopenhauer. In his The Province of Jurisprudence Determined (1832), he defines law as a generally applicable command, and command as the intimation of a wish together with a threatened sanction:

If you express or intimate a wish that I shall do or forbear from some act, and if you will visit me with an evil in case I comply not with your wish, the expression or intimation of your wish is a command. A command is distinguished from other significations of desire, not by the style in which the desire is signified, but by the power and the purpose of the party commanding to inflict an evil or pain in case the desire be disregarded. If you cannot or will not harm me in case I comply not with your wish, the expression of your wish is not a command, although you utter your wish in imperative phrase. If you are able and willing to harm me in case I comply not with your wish, the expression of your wish amounts to a command, although you are prompted by a spirit of courtesy to utter it in the shape of a request. (Lecture I/1995: 21)

Austin then adds: "Being liable to evil from you if I comply not with a wish which you signify, I am bound or obliged by your command, or I lie under a duty to obey it" (Lecture 1/1995: 22). Imperatives or laws, and more generally all commands, thus presuppose a threat of punishment because that is the only possible source of their binding quality.

Reflection on these accounts of law and obligation suggest two ways in which Schopenhauer's thesis may be refined to good effect. The first concerns a point on which the philosophers quoted above disagree, namely, whether the binding force of an ought, imperative, or law must come from a threat of punishment or whether it could also come from a promise of reward. Schopenhauer thinks it can be either, and in this 
he agrees with Locke and Paley. But Pufendorf and Austin indicate that a law or command must be backed specifically by a threat of punishment. ${ }^{6}$ Austin is adamant about this. "Rewards," he admits, "are, indisputably, motives to comply with the wishes of others. But to talk of commands and duties as sanctioned or enforced by rewards, or to talk of rewards as obliging or constraining to obedience, is surely a wide departure from the established meaning of the terms" (Lecture 1/1995: 23). The point is well taken, and I believe Schopenhauer would do well to join Pufendorf and Austin in supposing that a law or binding imperative must be backed specifically by a threat of punishment. For this reason, as well as for the sake of concision, I will in what follows tend to eschew the talk of promised rewards and focus instead on threats of punishment.

The second refinement concerns the scope of Schopenhauer's thesis. He asserts that every ought is conditioned through a threat or promise. On its face, however, that is too strong. Moral oughts are one thing. But there are other kinds of oughts that do not seem to be conditioned in this way. Consider for example the prudential imperative You ought to brush your teeth regularly. Except in the case where one has been commanded as much by an authority ("Brush your teeth or else!"), there is no promise of reward or threat of punishment conditioning this ought. Of course, it is true that "obeying" this imperative offers various benefits, such as better dental health, less pain, and so forth, and that "disobeying" it invites various bad consequences-pain, discomfort, diminished ability to eat certain foods, and so forth. One might therefore argue that this ought is conditioned through an expected benefit or the expectation of bad consequences. But an expected benefit is not the same as a promised reward, nor is an expected bad consequence the same as a threatened punishment. A promised reward is a desirable thing which is offered to induce someone to do (or not do) something, just as a threatened punishment is an undesirable thing which is threatened to induce someone to do (or not do) something. But the expected benefits of brushing one's teeth are not offered, nor the bad consequences threatened, for the purpose of inducing us to brush our teeth. It would therefore seem to be a misuse of language to say that such an ought is conditioned through a promised reward or threatened punishment. What Schopenhauer ought to say instead is that every binding ought is conditioned by a threat or promise. That is the key point that he needs for his argument: i.e., to the extent that an ought binds someone, it is conditioned by a promise of reward or threat of punishment.

Taking these refinements into account, we may take Schopenhauer's thesis to be simply this: that every binding ought presupposes, and is conditioned by, a threat of punishment.

\footnotetext{
${ }^{6}$ Kant makes a similar point about juridical legislation at MM 6:219.
} 
Schopenhauer himself offers little argument for this thesis. But it is not hard to see what the argument would be. If an ought (imperative, law) has a binding force, then then there must be some ground of this force, something in virtue of which the ought binds. But what could this ground possibly be if not the threat of some negative consequence? Just as we cannot be bound physically apart from some kind of externally imposed physical constraint, so also our wills cannot be bound apart from some kind of externally imposed motive constraint. Anyone who disagrees bears the burden of explaining how we could otherwise be bound.

Kant purports to find an explanation in the idea of self-legislation. On his view, any imperative that binds in virtue of an incentive or interest would thereby be conditioned and thus not suitable to be a moral command. It would result in what he calls heteronomy of the will:

Wherever an object of the will has to be laid down as the basis for prescribing the rule that determines the will, there the rule is none other than heteronomy; the imperative is conditional, namely: if or because one wills this object, one ought to act in such or such a way; hence it can never command morally, that is, categorically. (G 4:444)

For Kant, then, the binding force of the moral law cannot be grounded in any sort of threatened punishment. But then whence does it arise? His answer is to be found in the idea of autonomy, i.e., the idea that we each legislate the moral law for ourselves (G 4:432-44). Evidently his thought is that because we legislate the law for ourselves, our wills are bound or necessitated by themselves, and thus need not be necessitated by anything external to the will, such as a threat of punishment.

For my part, I fail to see how this helps. The idea of self-legislation certainly helps to account for the authority of the moral law; that is, it helps to explain how a law that constrains my will could do so legitimately. Likewise, the idea of self-legislation does help to explain how my will can be free in relation to a law that necessitates it. But the question that interests us here is not the question of authority or that of freedom, but the question of necessitation. The question is: What accounts for the necessitating or constraining quality of the moral law, that which elevates it from a mere intimation of a wish to a genuine law? But here the idea of self-legislation casts no real light. To ask how the moral law comes to necessitate one's will is to ask, in effect, why the alleged act of legislating for oneself is properly an act of legislation, or commanding, rather than merely the intimation of a wish (to use Austin's terminology). The answer cannot be that I am the author of what results from this act, because I am the author in both cases. To this, we may anticipate the response that my willing the moral law entails a kind of self-constraining of my will, in that it is my noumenal self who wills the law, and in so doing gives me special reasons to obey that law, reasons that override all other 
sorts of reasons. ${ }^{7}$ In view of their overriding quality, these special reasons, these moral reasons, can be said to constrain my will. But because they issue from my own willing, my will is not constrained by some external factor but is self-constrained. The binding or constraining force of the moral law hence comes from the fact that it is I myself, and in particular my noumenal self, who wills that law for myself.

The problem with this account, as I see it, is that having a reason to act in a certain way-even one of a sort that overrides reasons of all other sorts-does not constitute or entail a constraint on the will. And, in particular, having a reason to obey a law-even an overriding one-does not constitute or entail being bound or constrained by that law. To see why, it is important to distinguish those reasons which are our own, from those which are, as it were, imposed on us by others. Properly speaking, it is only reasons of the latter sort, those imposed on us from without, which can be said to bind or constrain our wills. Suppose on my way to class I encounter a person in need of medical attention. I have a prudential reason to go to class, but at the same time (let us suppose) an overriding moral reason to stop and help the person. Regardless of what I do, as long as the reasons that influence my will are my own reasons, then those reasons may be said to guide my will; but they cannot be said to constrain it. In contrast, if someone threatens me, thereby giving me a reason to do something I would not otherwise do, then clearly this kind of reason constitutes a constraint on my will. It is thus of the essence of constraint, or of binding, that it be imposed from without, and from this it follows that it is not possible for the will to constrain or bind itself. ${ }^{8}$

In contrast to Kant, the tradition represented by Pufendorf, Locke, Paley, Austin, and Schopenhauer offers a clear and intelligible explanation for the binding force of any prescriptive law: namely, it arises from the threat of a punishment (or perhaps the promise of a reward). Unless and until someone can make sense of the idea of a selfbinding will, we ought to side with this tradition.

With this, let us return to Schopenhauer's objections to the moral ought.

\section{The Theological Roots of the Moral Ought}

One of Anscombe's main claims in her paper on modern moral philosophy is that our central moral concepts-those "of obligation, and duty-moral obligation and moral

\footnotetext{
${ }^{7}$ For a fuller development of this thought, see, e.g., Young (1984: 202-6).

${ }^{8}$ Kant acknowledges this in effect in his discussion of duties to oneself at MM 6:417-18, where he invokes the distinction between homo phænomenon and homo noumenon to explain how one could bind oneself, his view being that the self insofar as it binds is not the very same subject as the self insofar as it is bound. But he cannot have it both ways. Either the legislator and the one subject to the law are the same subject, in which case we have genuine self-legislation but no explanation for the binding force of the law, or they are not the same subject, in which case we no longer have genuine self-legislation or autonomy.
} 
duty, that is to say-and of what is morally right and wrong, and of the moral sense of 'ought'" (1958: 1)-presuppose for their intelligibility a conception of ethics that has largely been abandoned, namely, a divine law conception. She writes:

Hume discovered the situation in which the notion "obligation" survived, and the notion "ought" was invested with that peculiar force having which it is said to be used in a "moral" sense, but in which the belief in divine law had long since been abandoned: for it was substantially given up among Protestants at the time of the Reformation. The situation, if I am right, was the interesting one of the survival of a concept outside the framework of thought that made it a really intelligible one. (Anscombe 1958: 6)

But essentially this same point had already been made by Schopenhauer more than a century earlier, in his essay On the Basis of Morality, where he takes aim at Kant's conception of a moral duty: ${ }^{9}$

This concept, together with its relatives, those of law, commandment, ought, and the like, taken in this unconditioned sense, has its origin in theological morals, and remains a foreigner in philosophical morals until it has produced a valid certification from the essence of human nature or that of the objective world. Until then I recognize for it and its relatives no other origin than the Decalogue. Overall in the Christian centuries philosophical ethics has unconsciously taken its form from theological ethics: and since this ethics is essentially one that commands, philosophical ethics too has appeared in the form of prescription and doctrine of duty, in all innocence and without suspecting that for this a further authority was needed first [....] Separated from the theological presuppositions from which they issued, these concepts really lose all meaning [Bedeutung] [...]. (BM §4, 122-23)

We have already seen that on Schopenhauer's view, a binding ought requires the threat of some punishment. But here he extends that idea. He notes that the moral ought, in particular, is supposed to bind us independently of "human rules, state institutions or religious doctrine" (BM §4, 121). And from this he draws the conclusion that the threat of punishment, from which the binding force of the moral ought arises, must issue from nothing less than a divine authority. Absent a divine lawgiver, then, the concept of a moral ought loses all sense and meaning. In attempting to articulate a philosophical ethics, therefore, Kant has unwittingly given us a theological ethics in disguise. This is Schopenhauer's second objection to the idea of a moral ought.

\footnotetext{
9 The extent to which Schopenhauer influenced Anscombe is difficult to ascertain, though we do have this report from Crisp (2014: 77): "Professor Peter Geach has told me (in private conversation, for which I am most grateful) that, as far as he knows, Anscombe had little direct knowledge of Schopenhauer's work, but that he and Wittgenstein would certainly have talked to her about Schopenhauer."
} 
It might be objected that Schopenhauer has overlooked a viable alternative to a divine legislator. Perhaps, one might suppose, the moral law is simply a brute fact of nature, which binds us in virtue of the "threat" of a guilty conscience. In that case, we could explain how the moral law binds independently of human rules without needing to appeal to a divine legislator. This suggestion, however, falls short. For one thing, the moral ought is supposed to bind universally, i.e., to bind all rational beings. Yet some people seem to have no conscience at all. Further, the moral ought is supposed to bind in a particularly strong way. But besides those who seem to have no conscience at all, there are many who have a rather weak or dull conscience. Schopenhauer is right, therefore, to think that a moral ought, as usually conceived, would have to issue from something transcending both humanity and nature, i.e., a supernatural lawgiver.

Schopenhauer and Anscombe agree on two main claims. The first is that the concept of a moral ought, along with the related concepts moral law and moral imperative, loses all sense and meaning, i.e., ceases to be intelligible, apart from a divine law conception of ethics. The second is that these concepts should be abandoned, at least as much as our psychology permits. On one important point, though, they disagree: namely, about the reason why these concepts should be abandoned. As for Anscombe, she thinks they should be jettisoned because, as a matter of historical fact, we-that is, we philosophers-have largely abandoned the divine law conception of ethics. Her thesis is that

the concepts of obligation, and duty-moral obligation and moral duty, that is to say-and of what is morally right and wrong, and of the moral sense of 'ought,' ought to be jettisoned if this is psychologically possible; because they are survivals, or derivatives from survivals, from an earlier conception of ethics which no longer generally survives, and are only harmful without it. (1958: 1)

In contrast, Schopenhauer contends that we ought to abandon these concepts not simply because they are passé, as it were, but because they are in fact incoherent, at least given human nature as we know it. These incoherencies are the subject of the next two sections.

\section{Two Kantian Contradictions}

By my count, Schopenhauer identifies at least three contradictions in the idea of a moral ought. The first two, which specifically target Kant's conception of the moral ought, will be considered in this section. (I view these collectively as Schopenhauer's third objection.) The third contradiction, which is more broadly applicable, will be considered in Section 5. 
The first contradiction stems from Kant's conception of the moral ought, or rather the related notion of the moral law, as a law of freedom. (Recall that in Kant's terminology, a moral ought expresses a moral or categorical imperative, which is a form of the moral law.) As he understands it, the moral law is a law of freedom in the surprising sense that freedom of the will consists in nothing other than the will being a law unto itself: "what, then, can freedom of the will be other than autonomy, that is, the will's property of being a law to itself? [...] hence a free will and a will under moral laws are one and the same" (G 4:447). From Schopenhauer's perspective, however, such a "law of freedom" is in fact a contradiction in terms: "It is of course a manifest contradiction to call the will free and then to prescribe laws that it ought to will by:'ought to will'-wooden iron!" (WWR 1, §53, 320-21). As we have seen, the moral law is said to bind or constrain our wills. But this is the very opposite of the idea of a free will: a will is free only to the extent that it is not bound or constrained. To speak of a law of freedom, at least in the sense of a binding law, is thus to contradict oneself.

The second and more important contradiction arises from Kant's conception of the moral ought as a categorical or unconditioned imperative (WWR 1, §53, 320; Appendix, 620). Given what has already been said, it is easy to see why Schopenhauer perceives a contradiction here. On his view, as indeed on Kant's, an imperative is a kind of command, and as such it necessarily binds. But nothing can bind an agent apart from some threatened punishment (or perhaps promised reward). As Schopenhauer notes, "It is simply impossible to think of a commanding voice, whether it come from within or from without, except as threatening or promising" (BM §4, 123). An imperative therefore necessarily presupposes, and is thus conditioned by, a threatened punishment (or promised reward). But then it follows that an "unconditioned imperative" would be both conditioned and unconditioned, and thus contradictory. Or, to put the point another way, such an imperative would be categorical and at the same time conditioned, and thus hypothetical: a non-hypothetical hypothetical imperative.

If the argument of Section 2 is correct, then Schopenhauer is right about these contradictions. There simply cannot be any such thing as a binding law of freedom or an unconditioned binding law. Having said that, though, it should be emphasized that, although these contradictions do pose a problem for Kant, they do not categorically refute the conception of morality as prescriptive; for a proponent of that conception need not traffic in these Kantian concepts. There is no reason why a prescriptivist could not admit that the moral law genuinely restricts our freedom and thus is not in Kant's sense a law of freedom. Likewise, a prescriptivist need not suppose that the moral law is unconditioned in Kant's sense, that is, absolutely unconditioned; she could instead grant that it is conditioned by some kind of possible sanction, perhaps imposed by a 
divine lawgiver. For such a prescriptivist, the contradictions described here would be beside the point.

Indeed, a prescriptivist of this stripe could even maintain that the moral ought, though not absolutely unconditioned, is nonetheless categorical in a rather robust sense. For consider: If I threaten to get you fired from your job if you do not lie under oath about our criminal dealings, then that threat will bind you, i.e., induce you to lie, only insofar as you desire not to be fired. If you really do not want to lose your job, then it will give you a strong reason to lie. But if for some reason you actually want to be fired, then the threat would not induce you to lie and would not be binding you but playing right into your hands; it would be a blessing disguised as a threat. Suppose, however, that the threat were not the loss of some subordinate good, such as one's job, but the loss of, say, happiness itself, perhaps in the form of eternal suffering. It is difficult to imagine that a human could ever view this as a blessing in disguise. The loss of a subordinate good might well be desired, as the only means to the end of achieving some more desirable good. But the loss of a good that one desires for its own sake, and for its own sake alone, could never be the means to some end. Thus, if the threatened punishment backing a command were the permanent loss of one's very happiness, then that imperative, though conditioned and hypothetical, could nonetheless be considered categorical in a rather robust sense.

\section{Imperatives and Self-Interest: A Third Contradiction}

In On the Basis of Morality, Schopenhauer identifies a third contradiction in the idea of a moral ought, one that in my opinion cuts to the heart of the matter. He gestures at the problem early in the essay: "a moral way of acting that was set in train merely by threatened punishment and promised reward would be such a thing more in appearance than in reality; because it would surely rest at bottom on egoism" (BM §2, 112). In his fuller critique of prescriptivism in $\S 4$, he interweaves this point with his discussion of the contradiction in the notion of an unconditioned ought in a way that makes it easier to overlook. He states:

It is simply impossible to think of a commanding voice, whether it come from within or from without, except as threatening or promising: but then obedience towards it will indeed be prudent or stupid, according to circumstances, yet always self-interested, and so without moral worth. (BM §4, 123)

After returning to the point about unconditioned oughts, he then adds:

[T] he conditioned ought can clearly not be an ethical grounding concept, because everything that happens with an eye towards reward and 
punishment is necessarily an egoistic deed and as such without purely moral worth. (BM §4, 124).

Schopenhauer does not explicitly describe this as a contradiction, but that seems the clear implication. In a nutshell, the problem is that a binding ought (imperative, law) operates through self-interest, whereas on Schopenhauer's view, as on Kant's, morality is fundamentally opposed to self-interest. The idea of a moral ought therefore involves a contradiction: in brief, it expresses the idea of something which operates through self-interest yet is opposed to self-interest. This is Schopenhauer's fourth objection to the moral ought.

Let us attempt to unpack this objection by fleshing out Schopenhauer's argument. I suggest that it goes something like this:

1. The moral ought (law, imperative) is a binding ought.

2. An ought can bind only in virtue of a threat of punishment. ${ }^{10}$

3. That which binds only in virtue of a threat of punishment can induce one to act (or refrain from acting) only insofar as one's end is the avoidance of that punishment.

4. Insofar as one's end in obeying an ought is the avoidance of the punishment, from the threat of which its binding character arises, one's obedience springs from self-interest.

5. Insofar as one's obedience springs from self-interest, it lacks moral worth. ${ }^{11}$

6. Thus, insofar as one acts with a view to obeying a binding ought, one's action eo ipso lacks moral worth. (from 2-5)

7. An ought having the property that, insofar as one acts with a view to obeying it, one's obedience eo ipso lacks moral worth, is not a moral ought.

8. Hence, the moral ought is not a moral ought, i.e., involves a contradiction. (from $1,6,7)$

In this argument, premise (6) follows from premises (2)-(5), and the conclusion, (8), follows from (1), (6), and (7). Of the non-inferred premises-that is, (1)-(5) and (7)-three seem to be self-evident or at the very least uncontroversial: (1), (3), and (7). The moral ought (or law) is universally conceived as something that binds us, that is, induces us to act or refrain from acting in certain ways: so (1) is true. As for (3), given the equivalence between binding and inducing one to act (or refrain from acting), it is obvious that what

\footnotetext{
${ }^{10}$ Here I continue my general practice of omitting the other side of egoistic inducement, i.e., the promise of reward.

11 Schopenhauer acknowledges that self-interest, or egoism, can work in combination with either compassion or malice: "Every human action must be traceable back to one of these incentives-although two of them can also operate jointly" (BM §16, 210). See also BM §15, 204: "Thus the discovery of a selfinterested motive entirely removes the moral worth of an action if it was the only motive, and reduces it if it had an accessory effect."
} 
binds only in virtue of a threat of punishment can induce one to act (or refrain from acting) only insofar as one's end is the avoidance of that punishment. And as for (7), it seems clear that if obeying an ought (or law) for its own sake-that is, not incidentally but because it is an ought (or law)-deprives an action of any moral worth it might otherwise have had, then that ought cannot be a moral one. In the end, therefore, the argument hinges on the plausibility of premises (2), (4), and (5).

Here I want to consider two objections to this argument. The first is that (2) is ambiguous in a way that compromises the argument. This premise says that an ought can bind only in virtue of a threat of punishment. If this means a punishment for the one who would disobey the ought, then the rest of the argument goes through. But on that reading (2) seems false; for it seems that an ought could bind someone by threatening harm not to the person themselves but to others whom they love. In that case, the ought would bind, but the person might well obey it not out of self-interest but purely out of compassion. So on a narrow reading of (2), according to which the agent herself is threatened, that premise seems false, whereas on the broader reading, according to which the threat is directed against either the agent or her loved ones, (2) would be true but (4) would be false. Either way, the argument is in trouble.

This, however, is not a deep objection to the argument. It is true that in particular cases an ought can bind in virtue of a threat of harm against others for whom one cares. But the moral ought is a moral law and as such does not merely bind a particular individual who happens to care about other people; rather, it binds all rational humans, even ones who do not love others. Human nature being what it is, no generally applicable imperative or law could bind all humans in virtue of their love of others. But self-interest is universal among humans, and appealing to it is the only way that an ought could bind all humans. In virtue of the universal applicability of the moral ought, then, (2) is in fact true. To make this explicit, we can revise premises (1), (2), and (6) of Schopenhauer's argument, giving us this:

$1 '$. The moral ought (law, imperative) is universally binding.

2'. An ought can bind universally only in virtue of a threat of punishment for the one who would disobey it.

3. That which binds only in virtue of a threat of punishment can induce one to act (or refrain from acting) only insofar as one's end is the avoidance of that punishment.

4. Insofar as one's end in obeying an ought is the avoidance of the punishment, from the threat of which its binding character arises, one's obedience springs from self-interest.

5. Insofar as one's obedience springs from self-interest, it lacks moral worth. 
6'. Thus, insofar as one acts with a view to obeying a universally binding ought, one's action eo ipso lacks moral worth. (from 2'-5)

7. An ought having the property that, insofar as one acts with a view to obeying it, one's obedience eo ipso lacks moral worth, is not a moral ought.

8. Hence, the moral ought is not a moral ought, i.e., involves a contradiction. (from $\left.1^{\prime}, 6^{\prime}, 7\right)$

In this version of the argument, $\left(2^{\prime}\right)$ stands immune to the objection and does indeed seem true.

The other objection concerns premise (5), the claim that one's obedience lacks moral worth to the extent that it springs from self-interest. This seems to me the crux of the argument.

It also seems quite plausible. There are indeed motives for obeying a law that might render one's obedience morally good and praiseworthy. For example, one might obey a law simply because it is the right thing to do, either because the law itself is good or because one has consented to obey it. Alternatively, one might obey a law out of respect for the lawgiver. In such cases, one's obedience might well be thought to have moral worth. But if one obeys a law simply because doing so benefits oneself, then one's obedience would not seem to be morally good or praiseworthy. And this seems especially clear in the case at hand, where one obeys the law in order to avoid the associated punishment. That is the kind of obedience we expect from criminals, not saints.

Of course, one philosopher who would not object to this premise is Kant, the primary target of Schopenhauer's argument. To the contrary, he maintains that an action can have moral worth only insofar as it is done not out of self-interest, but out of duty, or in other words, respect for the moral law. That law, as he says, "demands of us disinterested respect [uneigennützige Achtung]" (CPrR 5:147). Some philosophers would nonetheless object to premise (5) of Schopenhauer's argument. Here I will consider what I take to be their most promising line of attack: namely, to grant that selfinterest does detract from an action's moral worth, but to insist that one's selfinterested obedience might still have some degree of moral worth because obeying the law is after all the right thing to do. This is the familiar idea of "doing the right thing for the wrong reason," as we say.

To make this idea more concrete, let us consider an example. Suppose a person decides to tell the truth in a certain situation, not because the moral law commands it, or out of respect for the truth or anything like that, but simply because she calculates that speaking truthfully would be in her best interest. We might grant that her motive of advancing her interests in no way endows her action with moral worth; still, we might 
also think that her action has some moral worth simply because she does the right thing; that is, she tells the truth.

I want to say three things in response to this objection. First, even if it were true that a self-interested action could have moral worth in virtue of being the "right action", there is still something problematic about a supposedly moral ought that operates by binding humans in a way that reflects poorly on us from a moral point of view. If there were such a thing as a moral law, we would expect its normal mode of operation to be one that tends to redound to an agent's moral standing. One might thus still balk at calling any law that operates through self-interest a moral ought.

Second, and more importantly, it just seems false to say that an action has some degree of moral worth just in virtue of being the "right action," even if it is done for the wrong reason. For consider the following cases. Suppose, on the one hand, that I perform a kind act for a helpless neighbor, but only in order to gain her confidence so that I can take advantage of her for my own financial gain, for example, by pocketing some of her valuable jewelry. Now compare this to a case in which I simply break into the neighbor's house in order to steal her valuables. If doing the right thing, even for the wrong reason, suffices to endow one's action with some degree of moral worth, then it seems we would have to say that the first complex of actions-helping, then stealing-has some moral worth, whereas the second complex of actions-breaking, entering, and stealing-has none, since the first complex of actions, unlike the second, does include an action that is a "right action", namely, that of helping someone in need. But this seems clearly false. Neither complex of actions has any (positive) moral worth. Both are bad actions, and indeed if anything, the first complex of actions may be worse than the second, because manipulating a person in order to rob them may be worse than merely breaking into their house for the same purpose.

Finally, I think we can see, upon further reflection, why instances of doing the right thing for the wrong reason do not have moral worth. In short, the reason is that motives, and motives alone, are the ultimate source of moral worth. ${ }^{12}$ To see why, consider the following difference between actions and motives. Actions, on the one hand, are never in themselves morally good or bad-that is, when considered without respect to either their effects or the motives from which they spring. Take, for example, the case of lying. Kant notoriously argues that it is always wrong to lie. But this is false. As Schopenhauer himself convincingly argues in On the Basis of Morality, there is nothing morally wrong with lying in self-defense, e.g., to protect one's privacy from prying minds, or with a beneficent lie, e.g., lying to protect a loved one from some harmful truth (BM §17, 222-26). The same can be said of killing: taking a life in selfdefense, or in order to protect others from someone who threatens murder, can be

\footnotetext{
12 For recent defense of this view, see Slote (2001).
} 
morally acceptable. Like lying, killing is not in itself right or wrong. And the same can be said of all other actions, so long as they do not advert to a motive in their description. ${ }^{13}$ But contrast this, on the other hand, with motives. Morally good motives, such as love and compassion, are always in themselves morally good. To the extent that an action flows from genuine love or compassion for another, that action necessarily has moral worth. Likewise, to the extent that an action flows from malice, it is necessarily morally bad. What this suggests is that motives are the true source of moral worth (or goodness), not actions. Actions are morally good only because, and insofar as, they stem from morally good motives. And for this reason there cannot be any action that is done for the wrong reason, i.e., that springs solely from a morally bad motive, and yet still has some moral worth. The objection under consideration is therefore mistaken.

None of this is to deny that we can make good sense of the idea of doing the right thing for the wrong reason. For we might take the "right thing" to be simply whatever action a morally good person would perform in the circumstances. For instance, in the situation in which a neighbor is in need, a morally good person would help that neighbor. In the abstract, then, helping a neighbor in need is the right thing to do, and if one helps a neighbor for the wrong reason, then one can be said to do the right thing for the wrong reason. But none of this entails that a particular instance of helping someone in need has any moral worth. It does so, rather, only insofar as one does the right thing for the right reason, i.e., out of love or compassion.

In view of all this, I conclude that Schopenhauer's argument is sound.

\section{Conclusion}

By my count, Schopenhauer raises four objections to Kant's idea of a moral ought (or moral law). Of these, the last cuts the deepest. Kant does not in fact beg the question against the purely descriptive conception of ethics; but even if he did, that would not categorically refute the prescriptivist view. The objection that the moral ought presupposes a divine lawgiver poses a problem only for those who shun theological ethics. And the objection that concepts such as law of freedom or categorical imperative are contradictory can be sidestepped by simply eschewing those Kantian constructions. The fourth objection, in contrast, presents a deep and serious problem for any proponent of a prescriptivist conception of morality. If I am right about this objection being sound, then Schopenhauer has successfully made his case against the

\footnotetext{
${ }^{13}$ Actions such as committing murder or acting cruelly might be offered as counterexamples, but they arguably advert to a motive, i.e., the woe of another.
} 
legislative-imperative conception of morality and in favor of a descriptive-explanatory approach. ${ }^{14}$

\section{Abbreviations}

BM Schopenhauer, Arthur. On the Basis of Morality. In The Two Fundamental Problems of Ethics, Christopher Janaway (ed.). Cambridge University Press, 2009.

CPR Kant, Immanuel. Critique of Pure Reason, Paul Guyer and Allen Wood (eds.). Cambridge University Press, 1998. Cited by page number from Ak, vols. 3 (A) and 4 (B).

CPrR Kant, Immanuel. Critique of Practical Reason. In Practical Philosophy, Mary J. Gregor (ed.). Cambridge University Press, 1996. Cited by volume and page number from Ak.

G Kant, Immanuel. Groundwork of the Metaphysics of Morals. In Practical Philosophy, Mary J. Gregor (ed.). Cambridge University Press, 1996. Cited by volume and page number from Ak.

MM The Metaphysics of Morals. In Practical Philosophy, Mary J. Gregor (ed.). Cambridge University Press, 1996. Cited by volume and page number from Ak.

WWR 1 Schopenhauer, Arthur. The World as Will and Representation, Volume 1, trans. and ed. by Judith Norman, Alistair Welchman, and Christopher Janaway. Cambridge University Press, 2010.

\section{References}

Anscombe, G.E.M. 1958. "Modern Moral Philosophy," Philosophy 33(124): 1-19.

Austin, John. 1832 [1995]. The Province of Jurisprudence Determined, ed. Wilfrid E. Rumble. Cambridge University Press.

Bojanowski, Jochen. 2017. "Kant on the Justification of Moral Principles," Kant Studien 108(1): 55-88.

Capaldi, Nicholas. 1966. "Hume's Rejection of 'Ought' as a Moral Category," Journal of Philosophy 63(5): 126-37.

Cartwright, David E. 1999. "Schopenhauer's Narrower Sense of Morality," in The Cambridge Companion to Schopenhauer, ed. Christopher Janaway. Cambridge University Press, 252-92.

Crisp, Roger. 2004. "Does Modern Moral Philosophy Rest on a Mistake?" Royal Institute of Philosophy Supplement 54: 75-93.

\footnotetext{
${ }^{14}$ My thanks to Tim Hinton and Patrick Hassan for helpful comments on previous drafts of this chapter.
} 
Foot, Philippa. 1972. "Morality as a System of Hypothetical Imperatives," The Philosophical Review 81(3): 305-316.

Hassan, Patrick. 2019. "Schopenhauerian Virtue Ethics," Inquiry, DOI: 10.1080/0020174X.2019.1629337.

Paley, William. 1785. Principles of Moral and Political Philosophy. Cambridge University Press.

Pufendorf, Samuel. 1673 [1991]. On the Duty of Man and Citizen According to Natural Law, ed. James Tully. Cambridge University Press.

Puryear, Stephen. 2017. "Schopenhauer on the Rights of Animals," European Journal of Philosophy 25(2): 250-269.

Puryear, Stephen. Forthcoming. "Schopenhauer and Modern Moral Philosophy," in The Schopenhauerian Mind, ed. David Bather Woods and Timothy Stoll. Abingdon: Routledge Press.

Slote, Michael. 1982. "Morality Not a System of Imperatives," American Philosophical Quarterly 19(4): 331-340.

Slote, Michael. 2001. Morals from Motives. Oxford University Press.

Taylor, Richard. 2000. Good and Evil. Amherst, NY: Prometheus Press.

Taylor, Richard. 2002. Virtue Ethics: An Introduction. Amherst, NY: Prometheus Press. Tsanoff, Radoslav A. 1910. "Schopenhauer's Criticisms of Kant's Theory of Ethics," The Philosophical Review 19(5): 512-34.

Welsen, Peter. 2005. "Schopenhauer's Interpretation of the Categorical Imperative," Revista Portuguesa de Filosofia 61(3/4): 757-72.

Williams, Bernard. 1985. Ethics and the Limits of Philosophy. Cambridge, MA: Harvard University Press.

Young, Julian. 1984. "Schopenhauer's Critique of Kantian Ethics," Kant Studien 75: 191-212. 